\title{
Escalas del Arte Amatorio en el poemario "Para construir el amor", de Carlos Tünnermann'
}

Por Margarita López Miranda

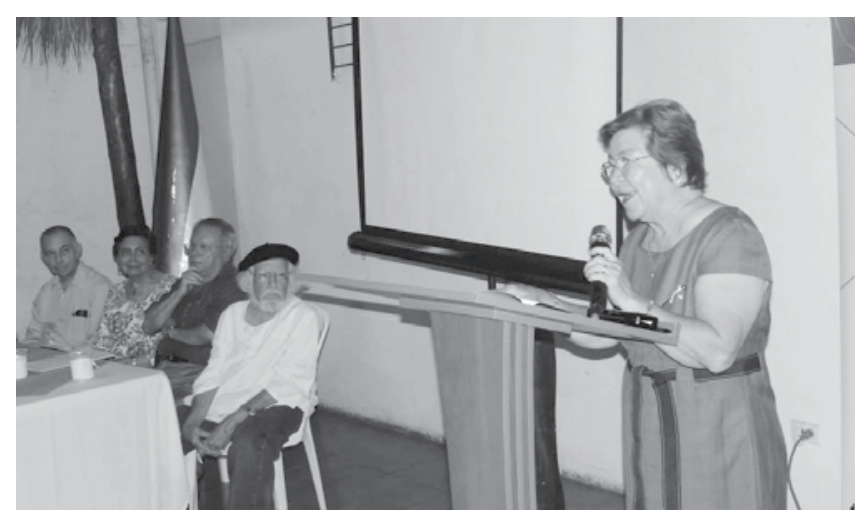

Profesora Margarita López Miranda en la presentación del poemario: "Para Construir el amor" del Dr. Carlos Tünnermann B.

$\mathrm{D}$ e las ocho secciones construidas por el verso de Carlos Tünnermann y que yo llamo "escalas" de ese Arte Amatorio, las tres primeras están dedicadas a cantar su amor fervoroso, romántico, erótico, nostálgico, pleno e inclaudicable de varón enamorado, esposo y compañero de vida, hacia la mujer amada, esposa, madre de sus siete hijos y musa permanente, su Rosa Carlota. Son las primeras escalas, con sus respectivos peldaños, en esa gradual ascensión que inicia con la intimidad amorosa, melancólica, sensual y de absoluta compenetración entre el yo y el tú, hombre y mujer, en inquebrantable y definitiva entrega. Bodas de Oro traspasadas ya por ese fluir de sonoridades dulces, cristalinas, vertidas por el "chorro de la fuente" que no se agota, pues esa transparencia sentimental se ha modelado con la solidez arquitectónica de un edificio de honda, cálida humanidad.

Así lo expresa el primero (I) y emblemático poema "Para construir el amor", guía de todo el poemario: "Sobre roca firme / - tú, una de cal; yo otra de arena

1 Pedagogo y escritor nicaragüense.

2 Catedratica e investigadora literaria, ensayista nicaragüense.

\section{RESUMEN}

Margarita López Miranda nos presenta un fragmento del ensayo escrito sobre el poemario: "Para construir el amor", del Dr. Carlos Tünnermann Bernheim, poemario construido en ocho secciones y que ella llama "escalas" de ese Arte Amatorio, cuyo sujeto es Rosa Carlota, musa, mujer amada, esposa y madre de sus hijos. Margarita López Miranda incorpora en su ensayo la afirmación de la escritora y crítica literaria Dra. Nidia Palacios, en el sentido de que: "otro poeta del amor conyugal ha entrado por la puerta grande de la mejor poesía amorosa, de la literatura nicaragüense.

Palabras clave: escalas, amor, beso, intensidad, ternura.

\section{ABSTRACT}

Margarita López Miranda presents us an essay fragment on the poems collection: "To build love", by Carlos Tünnermann Bernheim Ph.D, a poems collection written in eight sections and that she calls "scales" of that "Love Art", whose person is Rosa Carlota, Muse, beloved woman, wife and mother of his children. Margarita Lopez Miranda incorporates in her essay, the affirmation of the writer and literary critic Nidia Palacios Ph.D, in the sense that: "Another poet of married love has entered the big door of the best love poetry of the Nicaraguan literature".

Key words: scales, love, kiss, intensity, tenderness. 


\section{Literatura}

/ construimos este amor sin adjetivos / henchido de sustancia".

Describe pues, en esta primera ventana de su alma el edificio de su amor, sólido, compacto, "aplomado", enriquecido con la gracia de la sensualidad. De ahí que "pálpito a pálpito / "caricia a caricia"... / en jornadas inolvidables", que abarcan el día y la noche, sol y luna, los amantes entrelazados han ido construyendo su amor pleno, sin adjetivos. Al ritmo de un leit-motiv constructor hecho de cal y arena, los complementos amatorios de la mezcla humana definen el rumbo expresivo de la voz lírica que irá desplegándose peldaño a peldaño en esa escala de gradual ascensión del amor, desde lo íntimo y personal hasta sus manifestaciones más generales y universales.

(II.). "De las maneras de juzgar mi amor". Intensidad amorosa que juega con la oposición de lo que se expresa y lo que se esconde: palabras "que se resisten a entregarte su misterio". Más allá de las formas poéticas o despliegue de imágenes, hay un ritmo del sentir. Énfasis puesto en el sentimiento y pensamiento "obstinado, alucinante y posesivo".
(III.). "Primer beso". Con el paisaje de las Sierras de Managua como telón de fondo, el palpitante sexteto revela un primer trasvase amoroso de los enamorados juveniles: él, su primer beso; ella, "el primer desborde / de tu corazón de niña".

(IV.). "Si para amarte más..." Amor que por intensidad de la entrega es capaz de negar o detener el tiempo para vivir en la estación única de ese genuino sentimiento: “¡Sólo la dulce estación del amor!".

(V.). "Yo quiero un amor". Amor que trasciende y vence al tiempo, al olvido, a la muerte, las tres dimensiones de lo pasajero. De ahí que devuelve la mirada interior hacia la milenaria poesía china que junta sus almas, la de él y la de ella, convirtiéndolas en "dos pájaros de vuelo inseparable". Disolución gustosa del yo masculino tiernamente aferrado al tú femenino.

(VI.). "Amarte es..." Sensualidad amorosa del yo amante que se derrama en todos los sentidos de la mujer amada. El olor: "Presencia / como fragancia de rosas". Simboliza también el nombre real de ella. Tacto: "no hay mejor lugar / que tu costado". Todos

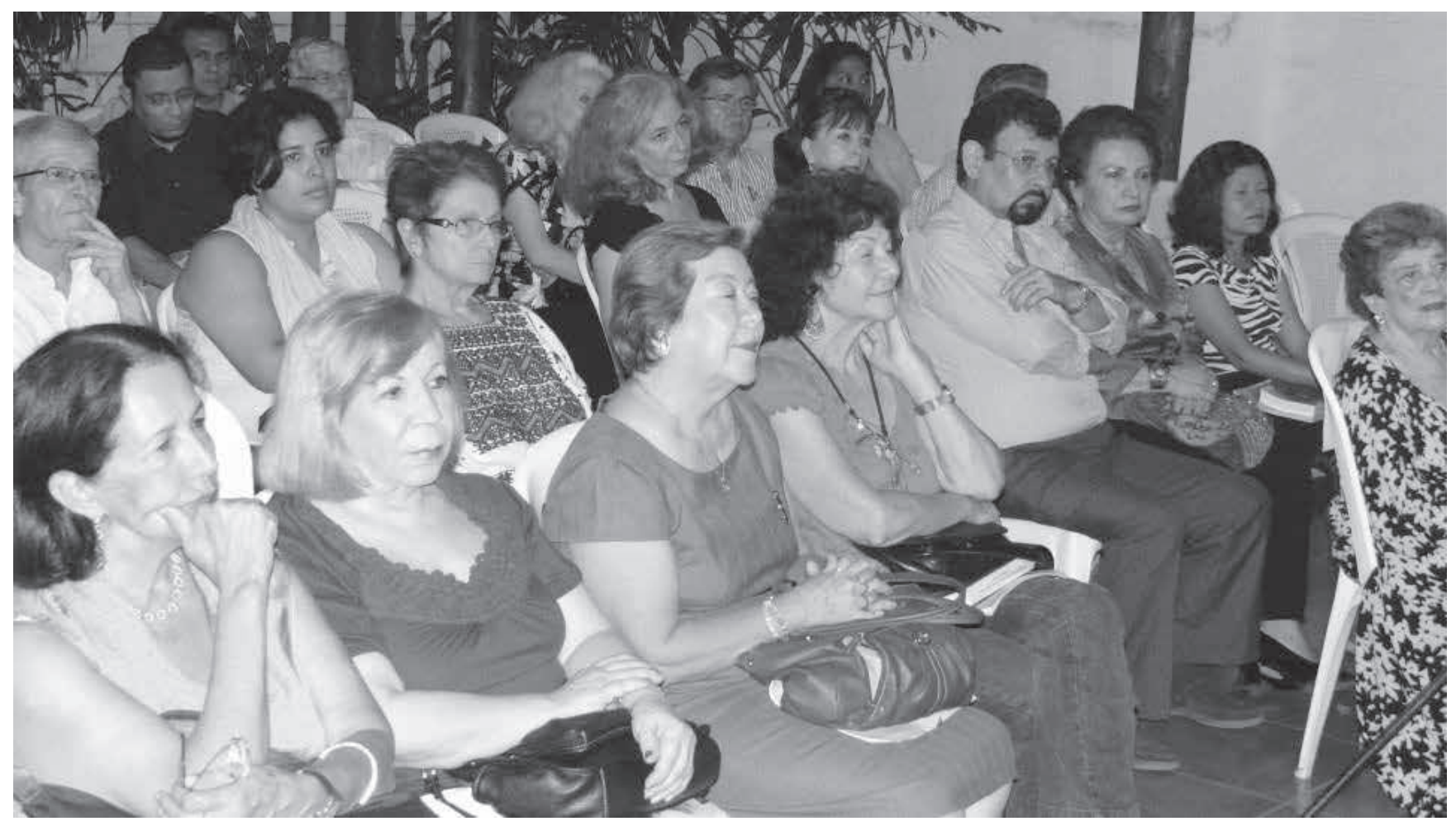

Parte del público asistente. 


\section{Literatura}

los sentidos: "Disfrutar tus manos, tus ojos y tu boca". El gozo pleno del cuerpo, la carne, la mujer de carne y hueso. Es la "Varona inmortal, flor de mi costilla", en la evocación dariana del epígrafe que acertadamente coloca el autor en la dedicatoria del poemario a su bienamada Rosa Carlota.

(VII.). "Primavera". Alegría plena en este renacer del Amor sensual, reproductor, vital: "Vida, sexo y flor", "granos de polen", "florecen soterrados deseos", "ansias dormidas". Las "nieves vencidas" aluden a un ambiente de país templado, natural en un poeta que ha viajado y vivido en diversos países por sus múltiples y trascendentes trabajos y cargos.

La sobriedad y elegancia de la palabra es característica de todos estos hermosos versos evocativos del ser amado. El autor del prólogo, Maestro Anastasio Lovo, con fina sensibilidad crítica valora el estilo con una feliz expresión: "ladrillos de cristal de sus versos claros". Después agrega: "Así como arma su amor, Tünnermann construye su poesía con pulcritud y transparencia juanramoniana, evitando la adjetivación excesiva, yendo a la sustancia, a la transparencia de imágenes poéticas producto de un equilibrio entre un sentimiento (interior) y una circunstancia (exterior)".

(VIII.). "Evocación". El yo poético pareciera dialogar con quienes contemplan el paisaje otoñal parisino. De ahí el acuerdo inicial "convengo". El tema contrasta la belleza de la urbe que dio cobijo a tanta poesía nuestra, Darío, entre muchos extraordinarios cantores. Ahí mismo y ahora, el poeta que nos ocupa contrasta la belleza de París con su tristeza personal, su nostalgia por ausencia de la mujer amada. Y perenniza su imagen vinculando su sonrisa con "el Sena legendario".

(IX.). "Ahora, amor mío". (Para Rosa Carlota en nuestro Quincuagésimo Aniversario). Con énfasis reiterativo, anafórico: "Ahora, amor mío", como guía de las etapas amorosas vividas junto a su Rosa Carlota, el amor hace un recuento retrospectivo a propósito de las Bodas de Oro de casados. La belleza de la mujer en la edad madura: "canas" que "dan inusitado esplendor a tu cabello", "rostro más sereno". "Sonrisa de madre / y de amorosa abuela". Junta las edades femeninas con admiración y expresa su felicidad que trastoca el tiempo, uniendo en su propio sentir juventud y madurez como signo de lealtad y perseverancia de rendido caballero ante su omnipresente Dulcinea: "iComo amo a la niña y a la joven / que descubro siempre en tu mirada!".

(X.). "50 Aniversario". Tema similar al anterior. Reencuentro reflexivo y amoroso. El ser amado llena el recuerdo, acompaña y guía el futuro. Avizora, seguro de la unión amorosa, el paso al infinito. Lugar y tiempo domeñados por la solidez de la unión y complementación vital: "Aquí, ahora, allá, después". Amor que llena la vida en el diario caminar. Enlace del presente y plataforma de la eternidad.

(XI.). "Tú y yo" "siempre". Recuerdo, a manera de saudade, de la mujer amada en imágenes juveniles. Parte del contexto de las Bodas de Oro. Revive ilusionado diálogo de requiebros amorosos, de tanteos declaratorios entre los enamorados. Traspasa y vence la barrera del parentesco y triunfa el destino de la flecha de Cupido, uniendo el tú y el yo para la vida entera. Juego verbal dialéctico y sensual entre románticos contendientes. De ahí la evocación de Bécquer, en la realización del ideal por correspondencia del ser amado. Así, la transformación del tú y yo individual en la plenitud del nosotros, mediante un trasvase del ser: "Somos tú y yo". El anillo, imagen del círculo amoroso, sello de identidades que se hace una sola: "Tú y yo siempre".

\section{"Poemas para recordarte".}

De los 17 poemas que componen esta sección, los primeros 10 aparecen sin título, encabezados por números romanos. Los restantes 7 van titulados. Llama mi atención dos detalles: 1. El poema inicial (I), crea un ambiente ritual, amoroso: "Oficio en el largo rito / de la espera...". Así, logra el ascenso poético del sentimiento amoroso a un nivel cercano a lo venerable. 2. De los siete restantes, el penúltimo, "Del origen de las locuras", y como anuncio del final, se refiere a los Siete días de la Creación Divina. En delicado juego irónico-creativo, y en tal sentido, contrariando la Palabra Bíblica, nos dice: "Y el séptimo día, / en vez de descansar / el Creador siguió creando / y creando sin cesar.../ todas las formas de locura". Y concluye bella 


\section{Literatura}

y febrilmente afirmando ser su vida una "locura de amor" causada por la mujer amada y consecuencia de esa locura creadora de la propia Divinidad. Con este marco Amatorio llevado al rango de lo venerable y emparentado con la locura propia de lo creativo, el Arte de Amar expresado por el verso de Carlos Tünnermann sella su carácter simbólico y originalidad estética.

\section{Veamos entonces algunos matices de la nostalgia y recuerdo amoroso a través de los poemas:}

(I). La espera y ansiedad por el ser amado se compara, como decíamos, con un rito preparatorio del encuentro. (II). El estado de ánimo del yo poético cambia según

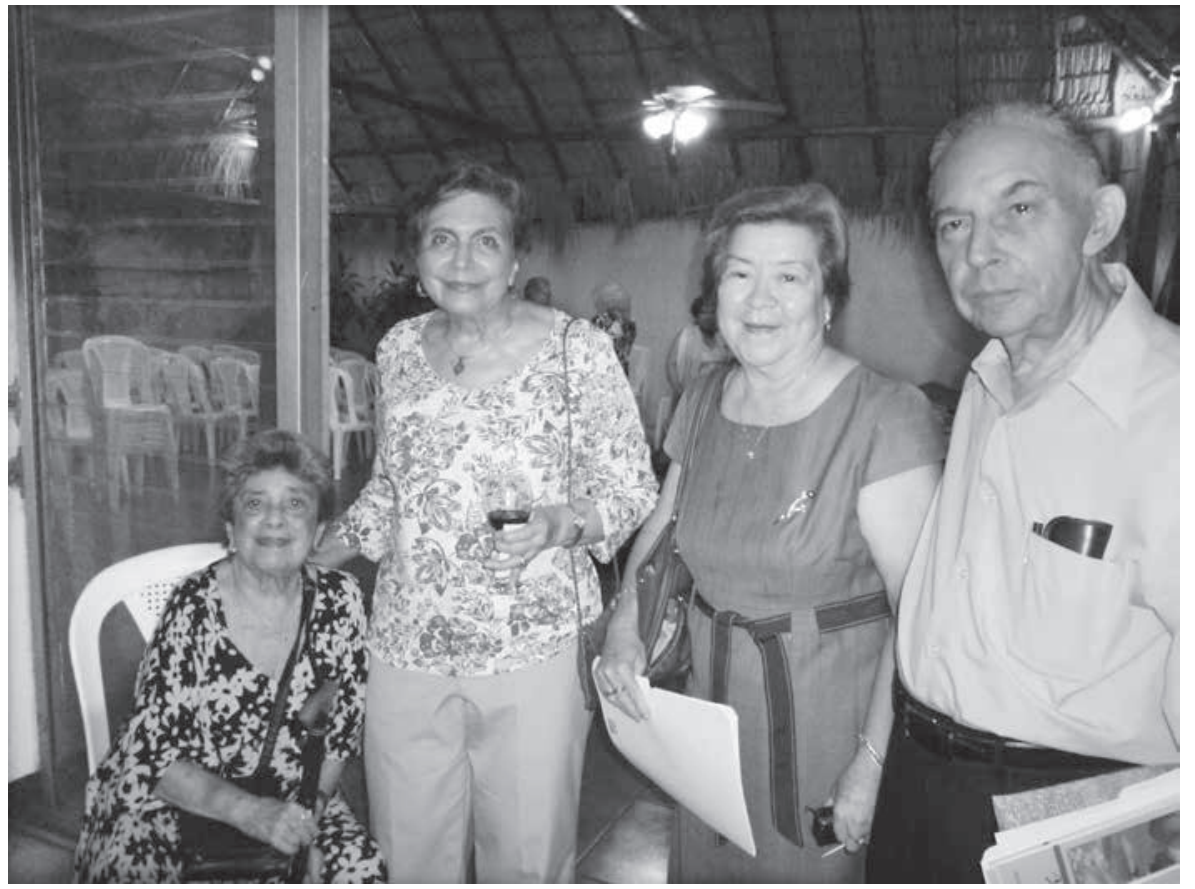

De izquierda a derecha: Escritora Claribel Alegría, Pintora Rosa Carlota Tünnermann, Académica y escritora Margarita López Miranda y el Dr. Carlos Tünnermann Bennheim. la cercanía o lejanía de la imagen evocada. En el primer caso, la imagen es concreta, palpable. En el segundo, implica desolación. (III). Prodigio sensual, la vista, el tacto, el oído, en función del recuerdo amoroso. (IV). Incorpora el ambiente físico, el espacio del hogar, que se hace inhóspito, vacío, sin la presencia de ella. "Esta casa no la habito, / me refugio en ella / hasta el día feliz de tu regreso".

(V). El mar, lugar del baño Amoroso. Nostalgia de la relación sensual y delicada de las olas con el "cuerpo de ámbar" de su fémina. (VI) Juegos de amor sensual, concreto, mediante imágenes sensoriales. Cada sentido de lo femenino relacionado con un matiz sentimental: beso de los ojos = nostalgia; beso de la mano = unión amorosa; beso de la boca = esperanza.

(VII). Persiste la relación sentimental - sensorial: "Amor, beso, labios, despedida". Imágenes que sugieren nostalgia y a la vez son expresiones concretas de fuerza romántica: "Ahora sólo me queda / tu imagen remachada / a mis pupilas". (VIII). Acude, irónicamente, a la filosofía cartesiana para superar la soledad y el hastío y salvar o sanar esos sentidos en la fórmula Amor = existir: “¡Amo, luego existo!”.
(IX). El sentimiento amoroso se manifiesta en el tacto: "Llevo tu amor impreso / en la yema de mis dedos". Chorrea escalonadamente matices de intensidad, plenitud y posesión amatoria: "indeleble, único, mío, intransferible". (X). Reitera la relación imaginaria - sentimental. Imágenes concretas, fuertes, indican cierre, unión, acaparamiento amoroso. A la par, delicadas ilusiones astrales, a manera de gráfico celeste que recuerdan estilos vanguardistas: “Amarro mis sueños / para que no te escapes de ellos /

Mientras

una /

a una /

van cayendo /

las estrellas".

En esta segunda parte de la sección, los títulos anuncian la continuidad del vaivén nostalgia, sensualidad, arrebato, simbología de lo afectivo, que conforman este verbo poético.

"Fatigada la ilusión". Imágenes y metáforas claras, paralelísticas, evocativas del recuerdo amoroso. De ahí los paralelos "fatigada ilusión; sueños 


\section{Literatura}

descansados... Sube y baja / marea de recuerdos"... bullen, danzan, se precipitan". Las metáforas evidentes: "embudo del tiempo", "apaciento mis recuerdos" (relación pastoril), "empuño la esperanza" (fuerza sentimental), "para batirme con tu ausencia" (lucha con lo negativo de la ausencia).

"Tu ausencia". Sentimiento de orfandad y evasión de sí mismo por ausencia de ella y avivado por el hábitat de la pareja. Personificación del sentimiento que se hace palpable a través de cada lugar y objeto del hogar vacío sin ella. Es una original encarnación del vacío que deja la carencia física de la esposa y mujer añorada. Hay una tensión e intensidad bien graduada entre el sentimiento de ausencia que se instala como "dueña y señora" del entorno familiar y la ilusión amorosa que ahuyenta la soledad "cuando emerges de mis sueños".

"Diciembre". Simbolismo de diciembre. Poema que traspola dos épocas: el hogar matrimonial de la primera época, que se inaugura en septiembre. El hogar presente, madurez conyugal, "recién inaugurado" en diciembre. Mes navideño, nacimiento de Jesús que inaugura con su venida la esperanza del más puro y elevado de los amores. Es diciembre intensificado por la vida juntos. El signo de felicidad será las "delicias hogareñas", es decir, la simbiosis pasado - presente conyugal en el sentimiento del yo lírico. De ahí la emoción evocativa: "tú serás mi esposa / y mi hijo / estará palpitando / en tus entrañas".

"Aquí, largamente tendido". En estilo anafórico indicado por el propio título, evocación sensual, corporal, en tres gados de intensidad expresiva y en tres momentos: 1 . La "virgen presentida" 2 . La "mujer perseguida" 3. Plenitud sensual en el amanecer de la soñada ilusión amorosa.

"Estirando los brazos". Se regodea en la temática del amante disfrutando el cuerpo femenino. Relación simbiótica con el esplendor del día, culminando en la dicha del amanecer junto a su fémina. Hay un regocijo sensual en la evocación de los sentidos: "despierta la luz en tus pupilas", "Amanece el día en tu sonrisa", "en el lecho me espera / tu abrazo al despertar".
La noche significa una pausa, un descanso, un compás de espera, que satisface por la compañía de ella. La unión amorosa se manifiesta en el abrazo de su amada, vivificante, como la bella claridad del día. El abrazo de los cuerpos simboliza la visión de dos almas que despiertan cada día al amor.

“Del origen de las locuras". Ya señalábamos al inicio el juego irónico - creativo con el Séptimo día de la Creación Divina. Descanso del Señor que se vuelve locura creadora y entre muchas, la "locura de amor" que le causa la mujer, su mujer - musa.

Amor $=$ locura $=$ creación $=$ vida. El amor así es un estado especial, fuera de lógica, mágico, enajenante, pues se es el otro (otra). "Cuando estás desnuda". La sensualidad alcanza el clímax del regocijo en la imagen de su amada desnuda. Apasionada y a la vez tierna evocación de varón enamorado. Esa ternura eleva la emoción sensual y produce un delicado equilibrio que otorga un hálito espiritual a la sensualidad masculina. Así concluye su variado y diáfano registro de "Poemas para recordarte": "Cuando estás desnuda, amor mío / y te alcanza mi mirada/ no sientes que una suave caricia te recorre?".

Toda esta riqueza lírica quiero refrendarla con un atinado comentario conclusivo de la Doctora Palacios sobre el Poemario Para construir el amor: "En este libro, afirma, la deuda con Darío es innegable, además, los intertextos en los poemas de Tünnermann nos remiten a las lecturas de la lírica amatoria de Petrarca, de los poetas provenzales, Garcilaso de La Vega, los grandes clásicos del Siglo de Oro, los románticos, los modernistas, los grandes poetas contemporáneos. $\mathrm{Y}$ afirma que con esta publicación "otro poeta del amor conyugal ha entrado por la puerta grande de la mejor poesía amorosa, lírica amatoria de la mejor literatura nicaragüense".

(Fragmentos de un extenso ensayo de Margarita López Miranda intitulado: "Academia, Humanismo y Arte amatorio en la Obra y trayectoria de Carlos Tünnermann Bernheim"). 